\title{
The Effectiveness of an E-Book on Developing Mathematical Thinking Skills and Acquisition of Mathematical Concepts among 5th Graders in Gaza
}

\author{
Ibrahim Hamed Al-Astal, Ph.D \\ Associate Professor, Teaching Mathematics \\ Department Of Curricula and Teaching Methods \\ Islamic University of Gaza
}

\author{
Ahmad A. Abu Zaydah \\ M.ED. \\ Palestinian Ministry of Education \\ Palestine, Gaza Strip
}

\begin{abstract}
This study aimed to investigate the effectiveness of using an e- book on Developing Mathematical Thinking Skills and Acquisition of Mathematical Concepts Among 5th Graders in Gaza. The researchers adopted the experimental approach. The Quasi Experimental Design ( pre-post test for two groups) is adopted in the study, The sample of the study included (70) students from Bet Lahya Elementary School during the second term(2013-2014). The study sample consists of two classes have been randomly selected from the school 5th grade classes, one of them (36 students) has been chosen as experimental group and the other(34 students) as control group. Two tools were used, Mathematical thinking test and Mathematical Concepts Acquisition Test.

The results revealed that there were statistically significant difference at $(\alpha=0.05)$ between the scores means of the experimental group and control group in mathematical thinking skills test in favor of the experimental group. Moreover there are also significant differences at $(\alpha=0.05)$ between the scores mean of the experimental group and control group in Acquisition of Mathematical Concepts in favor of experimental group. $\eta 2$ and $d$ values which were calculated, indicated to large effectiveness of the used e-book on developing mathematical thinking skills and acquisition of mathematical concepts of $5^{\text {th }}$ Graders in Gaza.
\end{abstract}

\section{General Terms}

E- Book , mathematical thinking skills (Guessing, Modeling, Symbolism, Induction, Deduction), acquisition of mathematical concepts.

\section{Keywords}

e- book, mathematical thinking skills, acquisition of mathematical concepts, the fifth grade male students

\section{INTRODUCTION:}

Over the past decades, web-based learning has become a critical issue in education due to the large amounts of information and recourses available in online environments [1], [2]. In the light of technological development the role of the teacher changed from traditional aspect to a professional role that associated with technological development. Nowadays, mobile learning technologies have influenced many aspects of education, including the computing applications for teaching, such as tablet PCs, which provide new method for instructors to deliver content and motivate students to engage in various learning activities inside and outside the classroom [3], [4]. Among these aspects of technology ; digital devices can be used as e-book, this came at a time of rising of interactive technologies provides a chance to expand learners informal learning opportunities in a new direction, with the potential to support learners physical, social, and cognitive development [5]. Among the advantages of teaching with such e-books is the possibility offered to the student to participate actively during the lesson and make correlations and creative comparisons with either other lessons or other courses, thus supporting the interdisciplinary learning approach[6].

E-Book as Wexelbaum,et al. [7] mission is "electronic text that is available in a digitally encoded format readable via an electronic device" ( p. 2). PC magazine encyclopedia defines e-book as an electronic counterpart of a printed book, which can be viewed on a desktop computer, laptop, smartphone or e-book reader [8]. Hatipoglu and Tosun[9] add that, e-books provide new facilities in addition to having all the features of printed books but not being printed on papers, they consist of hardware and software (p129) .

Also e-book can be defined as any group of text in a digital format that is to be read and displayed on a computer screen[10]. According to another definition, Borchers [11] states that, it is "portable hardware and software system that can display large quantities of readable textual information to the user and lets the user navigate through this information"(p.1)

On the other hand, e-book consists of pictures, diagrams, symbols, signs, shapes and videos which can improve thinking skills. E-books as Ongoz and Baki,[12] state are useful tools for increasing the interaction between students, and between teacher and students, they are containing multimedia makes important contributions to the quality of students' learning (p.35).

The advantages of e-books for teaching are straightforward and include several factors: Increasing interaction, Promoting learning motivation, Encouraging student participation , Usefulness -Facilitating the understand of abstract concepts[13] (p.133) .

Mitropoulou [6] add that, e-books offers some advantages such as "offering to the students more opportunities for engaging and interacting with the books content, multiple representations of the content information, which are expected to result to the better imprint in the students' memory" (p.269).

One of the possible benefits of e-books over printed text as Beimers[14] confirms is the e-book's extra features, as adjustable font size, a built-in dictionary, and text-to-speech features, these features as Beimers mentioned make e-books better able to meet the diverse needs of students in the general education classroom ( $\mathrm{p} 7$ ).

This emerging technology has opened the possibility for a large range of new learning experiences for students because 
of its advantages over traditional printed textbooks. Electronic books often contain rich multimedia features that cannot be found in textbooks[10] .

Moreover, Chen and Jang[13] have pointed out that e-books are one type of critical learning platform with considerable potential for students to learn new knowledge in web-based context (p.131).

Maynard [15] also conducted a study comparing how much children learn from electronic text in comparison to printed text, The results showed that those who used the electronic textbook(e-book) did better on the comprehension tests than those who used the printed textbook .

According to Huang et al.[16], the response from 166 elementary school students shows that the e-book has more preference than printed book in terms of usability and functionality. Grimshaw, et al. [17] found that multimedia enriched content in e-books, such as narration along with animated pictures and sound effects shows improvement in children's learning .

In light of the results of the international studies (Trends in International Mathematics and Science Study [ TIMSS ]); the scores means in mathematics of 8th grade students in Palestine were $(390.367$ ، 404) in the years (2003, 2007, 2011) respectively, and the rank of Palestine in 2011 was (42) from (45) states[18], [19], [20]. These result showed the low level of our students in high order level questions in mathematics.

Teaching thinking becomes an urgent necessity imposed by the current time, and interest is no longer confined to efforts to help students to gain knowledge ,information , facts and educational concepts, but it goes beyond their mental abilities to develop thinking skills[21](p7). One of the most important thinking skills is the mathematical thinking skills such as (Inductive, Deductive, spatial visualization, mathematical proof, mathematical modeling, mathematical reasoning, guessing, Symbolism , generalization, problem solving, ...) which mathematics teacher can use in math classes and implement more activities to develop their students mathematical thinking skills. Student should be taught using technological materials and manipulatives such as e-books to enhance their mathematical thinking, also many previous studies in this area revealed that integrating teaching mathematics with technology and internet had significant effect in developing students thinking, mathematical achievement and concept attainment [22], [23], [24], [25].

\section{STUDY PROBLEM:}

\subsection{Statement of the problem}

Reviewing the related literature ,most of the previous researches was done with undergraduate students, but few have investigated the use of e-books for elementary school students, and investigated the impact of e-book on the development of students' reading skills as [26], [17], [27], [28], [29], while few researches have investigated the impact of using e-books with students in other subjects. There are hardly any studies related to use of e-book in teaching mathematics in elementary schools, Furthermore, no study has been undertaken to examine the impact of using interactive e-book in teaching school mathematics in Palestine.

Taking all these points into consideration, it is thought that this study will highlight trends of e-books and their importance as tools in teaching mathematics in elementary school.

\subsection{Study Questions}

The study problem is represented in the following questions:

1. What is the impact of using e- book in teaching mathematics on mathematical thinking skills (Guessing, Modeling, Symbolism, Induction, Deduction) of the elementary $5^{\text {th }}$ grade students in Gaza?

2. What is the impact of using e -book in teaching mathematics on mathematical concepts acquisition of the elementary $5^{\text {th }}$ grade students in Gaza?

\subsection{Study Hypotheses}

1. There are no statistically significant difference at ( $\alpha$ $\leq 0.05$ ) between the scores means of the experimental group and control group in mathematical thinking skills test.

2. There are no statistically significant difference at $(\alpha \leq 0.05)$ between the scores means of the experimental group and control group in mathematical concepts acquisition test.

\subsection{Study Purpose}

The purpose of this study is to investigate the impact of the ebook In developing mathematical thinking skills and concepts acquisition for $5^{\text {th }}$ grade students in Gaza.

\subsection{Content limitation}

This study has been limited by the $7^{\text {th }}$ unit of mathematics book of the $5^{\text {th }}$ grade( Measurement).

\section{METHOD}

The Quasi Experimental Design ( pre-post test for two groups) is adopted in the study, the two groups are randomly selected, One of them has been assigned as experimental group , and the other as control one. 3.1.Participants: The sample of the study included (70) students from Bet Lahya Elementary School during the second term(20132014). The study sample consists of two classes have been randomly selected from the school $5^{\text {th }}$ grade classes, one of them (36 students) has been chosen as experimental group and the other(34 students) as control group.

\subsection{Materials and Tools}

\subsubsection{The E-Book}

To design and develop the e- book for teaching mathematics to $5^{\text {th }}$ grade students, the standards of e-book design as [30], [31], [32] listed were taken in consideration, the researchers also prepared content analysis for the $7^{\text {th }}$ unit of mathematics book and used a model depends on what researchers as Khamis [33], [34] and Azmi and Al Mrdani [30] have developed, this model is consisted of five stages: Analysis, Designing, Development, Evaluation, Publishing and Implementation, as suitable model for developing such ebook. The proposed e- book and the teacher's guide were reviewed and corrected by a group of specialists in teaching mathematics and educational technology in Gaza universities.

\subsubsection{The pilot study}

The study tools (Mathematical Thinking Test and Concepts Acquisition Test) were prepared and reviewed by a group of specialists in teaching mathematics in Gaza universities, supervisors and teachers in (UNRWA) schools and Government schools. The tools were modified according to referees recommendations.

The tools were applied on a random sample of (30) students, from Bet Lahya Elementary School other than the study 
groups. The results were recorded and statistically analyzed to investigate its validity and reliability.

\subsubsection{Mathematical Thinking Test}

Mathematical thinking skills test has been developed with respect to the selected unit (Measurement), the test is consisted of (26) items, and distributed into five Sub Skills as it's listed in table (1)

Table 1 : Mathematical thinking test

\begin{tabular}{|c|c|c|}
\hline Sub Skills & No. & Items \\
\hline Guessing & 6 & $17,18,19,20,21,22$ \\
\hline Modeling & 4 & $23,24,25,26$ \\
\hline Symbolism & 4 & $13,14,15,16$ \\
\hline Induction & 5 & $1,2,3,4,5$ \\
\hline Deduction & 7 & $6,7,8,9,10,11,12$ \\
\hline
\end{tabular}

The Mathematical thinking skills test was reviewed and corrected by a group of referees, then test has been modified by the researchers.

According to the pilot study, the difficulty coefficients of the test items are ranged between $(0.26-0.69)$, and the discrimination coefficients ranged between $(0.25$ and 0.74$)$. The correlation coefficient between each item of the test and the total score is significance at $(0.05)$ or $(0.01)$, and the correlation coefficients between the score of each domain of the test and the total score is significance at $(0.05)$ or (0.01) also. According to these results, it can be concluded that the mathematical thinking test is highly consistent and valid as a tool for the study.
For determining the reliability of the test ,the test reliability coefficient is calculated by Split - Half Method and KuderRichardson 20 (KR-20) Formula they are (0.92), (0.89) respectively. This confirms that the test was highly reliable.

\subsubsection{Mathematical Concepts Acquisition Test}

Mathematical Concepts acquisition test has been developed with respect to the measurement unit content analysis, the test is consisted of (20) items.

The Mathematical Concepts acquisition test was reviewed and corrected by a group of referees, then test has been modified by the researchers. According to the pilot study ,the difficulty coefficients of the test items are ranged between $(0.27-0.70)$, and the discrimination coefficients ranged between $(0.28$ and $0.71)$. The correlation coefficient between each item of the test and the total score is significance at $(0.05)$ or $(0.01)$. Depending on these results, it can be concluded that the Concepts acquisition test is highly consistent and valid as a tool for the study.

For determining the reliability of the test ,the test reliability coefficient is calculated by Split - Half

Method and Kuder-Richardson Formula 20 (KR-20), they are (0.85), (0.87) respectively. This confirms that the test was highly reliable. $* *$

\subsection{Pre-test applying}

To make sure that the sample subjects are equivalent in their previous mathematical thinking skills and concepts acquisition, the researcher applied the mathematical thinking skills test and concepts acquisition test before applying the study as pre- tests. The results of the subjects were recorded and statistically analyzed using Independent Samples T- test . Tables (2) and (3) describe the results of the equivalence as follows:

Table 2 Significant differences between the experimental and control groups in the mathematical thinking skills pre-test

\begin{tabular}{|c|c|c|c|c|c|c|c|}
\hline $\begin{array}{l}\text { Mathematical } \\
\text { thinking skills }\end{array}$ & Groups & $\mathrm{N}$ & Mean & S D & $\mathrm{t}$ & $d f$ & $\begin{array}{c}p \text { value } \\
\text { (sig.) }\end{array}$ \\
\hline \multirow[t]{2}{*}{ Guessing } & Experimental Group & 36 & 1.33 & 0.986 & \multirow{2}{*}{-0.415} & \multirow[t]{2}{*}{68} & \multirow{2}{*}{$0.680^{*}$} \\
\hline & Control Group & 34 & 1.44 & 1.186 & & & \\
\hline \multirow{2}{*}{ Modeling } & Experimental Group & 36 & 1.42 & 1.105 & \multirow{2}{*}{0.359} & \multirow{2}{*}{68} & \multirow{2}{*}{$0.721 *$} \\
\hline & Control Group & 34 & 1.32 & 1.065 & & & \\
\hline \multirow{2}{*}{ Symbolism } & Experimental Group & 36 & 1.08 & 0.841 & \multirow{2}{*}{-0.698} & \multirow{2}{*}{68} & \multirow{2}{*}{$0.490 *$} \\
\hline & Control Group & 34 & 1.24 & 0.987 & & & \\
\hline \multirow{2}{*}{ Induction } & Experimental Group & 36 & 2.00 & 1.414 & \multirow{2}{*}{-1.688} & \multirow{2}{*}{68} & \multirow[b]{2}{*}{$0.096 *$} \\
\hline & Control Group & 34 & 2.56 & 1.353 & & & \\
\hline \multirow{2}{*}{ Deduction } & Experimental Group & 36 & 2.72 & 1.279 & \multirow[b]{2}{*}{0.927} & \multirow{2}{*}{68} & \multirow[b]{2}{*}{$0.357 *$} \\
\hline & Control Group & 34 & 2.41 & 1.520 & & & \\
\hline \multirow{2}{*}{ Total } & Experimental Group & 36 & 8.56 & 3.443 & \multirow{2}{*}{-0.512} & \multirow{2}{*}{68} & \multirow{2}{*}{$0.610^{*}$} \\
\hline & Control Group & 34 & 8.97 & 3.335 & & & \\
\hline
\end{tabular}


*Not sig. at $(\boldsymbol{\alpha}=0.05)$

Table (2) Shows the mean and the standard deviation of each group (experimental group and control group. The results revealed that there were no statistically significant differences between the scores means of the experimental group and control group at $(\alpha=0.05)$ in mathematical thinking skills test and sub skills (Guessing, Modeling, Symbolism, Induction, Deduction), Table (3) results revealed that there were no statistically significant difference between the scores means of the experimental group and control group at $(\alpha=0.05)$ in mathematical concepts acquisition test .

Table 3. Significant differences between the experimental and control groups in mathematical concepts acquisition pre-test

\begin{tabular}{|c|c|c|c|c|c|c|}
\hline Groups & $\mathrm{N}$ & Mean & $\mathrm{S} \mathrm{D}$ & $\mathrm{t}$ & $\mathrm{df}$ & $\begin{array}{c}p \text { value } \\
(\mathrm{sig} .)\end{array}$ \\
\hline $\begin{array}{c}\text { Experimental } \\
\text { Group }\end{array}$ & 36 & 5.56 & 3.121 & \multirow{2}{*}{1.305} & 68 & $0.196^{*}$ \\
\hline $\begin{array}{c}\text { Control } \\
\text { Group }\end{array}$ & 34 & 4.71 & 2.223 & & & \\
\hline
\end{tabular}

*Not sig. at $(\alpha=0.05)$

Thus suggesting that the initial mathematical thinking skills and mathematical concepts acquisition levels of groups were similar.

\section{PROCEDURES}

The study is progressing according to the following steps:

1. Determining the participants' of the study.

2. Analyzing the $7^{\text {th }}$ unit (Measurement) from the student's book in $5^{\text {th }}$ grade elementary school.

3. Designing and developing the study materials and tools( e book, teacher guide, mathematical thinking test, and concepts acquisition test ).

4. Applying the tools(mathematical thinking test, and concepts acquisition test) on the sample of the study as pre- tests .
5. Teaching the experimental group by using e book, while control group by traditional method through four weeks.

6. Applying the tools on the sample of the study as post- tests.

7. Analyzing and interpreting the results.

8. Presenting the suggestions and the recommendations in the light of the study findings.

\section{STATISTICAL ANALYSIS:}

\section{After collecting the data, the researchers used}

Independent- Samples t-Test, Eta-Square and $\mathrm{d}$ in order to measure the differences between the scores means of the experimental group and control group, and to identify the effect size of the e book in developing mathematical thinking, and concepts acquisition .

\section{STUDY FINDINGS AND DISCUSSIONS:}

The following results were achieved according to the study questions:

6.1. The first question is: "What is the impact of using e-book in teaching mathematics on mathematical thinking skills (Guessing, Modeling, Symbolism, Induction, Deduction) of the elementary $5^{\text {th }}$ grade students in Gaza?".

To answer this question, the researcher tested the following null hypothesis: "There are no statistically significant difference at $(\alpha<0.05)$ between the scores means of the experimental group and control group in mathematical thinking skills test".

To investigate the first hypothesis, mean and standard deviation of the experimental and the control groups' results were computed. Independent-Sample t-Test was used to measure the significance of differences. Table (4) describes the results as follows:

Table 4. Significant differences between the experimental and control groups in the mathematical thinking skills post-test

\begin{tabular}{|c|c|c|c|c|c|c|c|}
\hline $\begin{array}{l}\text { Mathematical } \\
\text { thinking skills }\end{array}$ & Groups & $\mathrm{N}$ & Mean & S D & $\mathrm{t}$ & $d f$ & $\begin{array}{c}p \text { value } \\
\text { (sig.) }\end{array}$ \\
\hline \multirow[t]{2}{*}{ Guessing } & Experimental Group & 36 & 4.31 & 1.653 & \multirow{2}{*}{7.208} & \multirow[t]{2}{*}{68} & \multirow{2}{*}{$0.000^{*}$} \\
\hline & Control Group & 34 & 1.76 & 1.257 & & & \\
\hline \multirow{2}{*}{ Modeling } & Experimental Group & 36 & 2.86 & 0.867 & \multirow{2}{*}{5.440} & \multirow{2}{*}{68} & \multirow{2}{*}{$0.000 *$} \\
\hline & Control Group & 34 & 1.74 & 0.864 & & & \\
\hline \multirow{2}{*}{ Symbolism } & Experimental Group & 36 & 2.44 & 1.252 & \multirow{2}{*}{4.613} & \multirow{2}{*}{68} & \multirow{2}{*}{$0.000 *$} \\
\hline & Control Group & 34 & 1.18 & 1.029 & & & \\
\hline \multirow{2}{*}{ Induction } & Experimental Group & 36 & 4.25 & 0.806 & \multirow{2}{*}{4.779} & \multirow{2}{*}{68} & \multirow{2}{*}{$0.000^{*}$} \\
\hline & Control Group & 34 & 2.76 & 1.671 & & & \\
\hline \multirow{2}{*}{ Deduction } & Experimental Group & 36 & 5.42 & 1.519 & \multirow{2}{*}{7.461} & \multirow{2}{*}{68} & \multirow{2}{*}{$0.000 *$} \\
\hline & Control Group & 34 & 3.00 & 1.155 & & & \\
\hline \multirow{2}{*}{ Total } & Experimental Group & 36 & 19.28 & 4.737 & \multirow{2}{*}{8.872} & \multirow{2}{*}{68} & \multirow{2}{*}{$0.000 *$} \\
\hline & Control Group & 34 & 10.44 & 3.457 & & & \\
\hline
\end{tabular}


Table (4) reveals that the calculated $t$ value is higher than $t$ value in the table. so the null hypothesis is rejected and accept the Alternative Hypothesis; statistically. Moreover there are also statistically significant differences between the scores means of the experimental group and control group in all four sub skills of mathematical thinking in favor of experimental group.

To calculate the effect size of e book, the researchers used Eta square " $\eta 2$ " by using the following equation:

$\eta^{2}=\frac{t^{2}}{t^{2}+d f} \quad$ and (d) value: $d=\frac{2 t}{\sqrt{d f}}$

Table 5: References to determine the level of effect size ( $\eta$ 2) and (d)

\begin{tabular}{|l|c|c|c|}
\hline \multirow{2}{*}{ Test } & \multicolumn{3}{|c|}{ Effect Size } \\
\cline { 2 - 4 } & Small & Medium & Large \\
\hline$\eta 2$ & 0.01 & 0.06 & 0.14 \\
\hline $\mathrm{d}$ & 0.2 & 0.5 & 0.8 \\
\hline
\end{tabular}

The following table describes $t$ value, $\eta 2$ and $d$ for each mathematical thinking sub skill and the total degree

Table 6: $t$ value, $\eta 2$ and $d$ for each mathematical thinking sub skills and the total score

\begin{tabular}{|c|c|c|c|c|}
\hline $\begin{array}{c}\text { Mathematical } \\
\text { thinking skills }\end{array}$ & $\mathrm{t}$ & $\eta 2$ & $\mathrm{~d}$ & Effect Size \\
\hline Guessing & 7.208 & 0.433 & 1.74 & Large \\
\hline Modeling & 5.440 & 0.303 & 1.319 & Large \\
\hline Symbolism & 4.613 & 0.238 & 1.118 & Large \\
\hline Induction & 4.779 & 0.251 & 1.159 & Large \\
\hline Deduction & 7.461 & 0.450 & 1.799 & Large \\
\hline Total & 8.872 & 0.537 & 2.152 & Large \\
\hline
\end{tabular}

In table (6) it can be seen that all results of " $\eta 2$ " and " $d "$ in a large level, that indicated a large effect of e book in improving mathematical thinking skills and the sub skills (Guessing, Modeling, Symbolism, Induction, Deduction) for the experimental group.

\subsection{The second question is}

"What is the impact of using e book in teaching mathematics on mathematical concepts acquisition of the elementary $5^{\text {th }}$ grade students in Gaza?" To answer this question, the researcher tested the following null hypothesis: " There are no statistically significant difference at $(\alpha \leq 0.05)$ between the scores means of the experimental group and control group in mathematical concepts acquisition test".
Table 7 Significant differences between the experimental and control groups in mathematical concepts acquisition post-test

\begin{tabular}{|c|c|c|c|c|c|c|}
\hline Groups & $\mathrm{N}$ & Mean & S D & $\mathrm{t}$ & $\mathrm{df}$ & $\begin{array}{c}p \\
\text { value } \\
\text { (sig.) }\end{array}$ \\
\hline $\begin{array}{c}\text { Experimental } \\
\text { Group }\end{array}$ & 36 & 12.53 & 3.525 & \multirow{2}{*}{9.814} & \multirow{2}{*}{68} & \multirow{2}{*}{$0.000 *$} \\
\hline $\begin{array}{l}\text { Control } \\
\text { Group }\end{array}$ & 34 & 5.29 & 2.529 & & & \\
\hline
\end{tabular}

* sig. at $(\alpha<0.05)$

There are no statistically significant difference at $(\alpha \leq 0.05)$ between the scores means of the experimental group and control group in mathematical thinking skills test

Table (7) reveals that the calculated $t$ value is higher than $t$ value in the table. so the null hypothesis is rejected and accept the Alternative Hypothesis; there are statistically significant difference at $(\alpha=0.05)$ between the scores means of the experimental group and control group in mathematical concepts acquisition test" in favor of the experimental group.

To determine the effect size,$\eta 2$ and $d$ are calculated, they are equal (0.586), (2.380) respectively, Thus suggesting large effect of e-book on experimental group students' acquisition of mathematical concepts.

\section{DISCUSSION}

This study used the pre-post test design to determine the effectiveness of using e- book in developing mathematical thinking skills and mathematical concepts acquisition of the elementary school for the fifth grade male students in Gaza. No statistically significant differences were found between the scores means of the experimental group and control group in mathematical thinking skills pre-test and sub skills (Guessing, Modeling, Symbolism, Induction, Deduction), in addition no statistically significant difference was found between the scores means of the experimental group and control group in mathematical concepts acquisition pre-est.

In general the results of the study reflect the superiority of the experimental group which used e- book compared with the control group in development of mathematical thinking skills and mathematical concepts acquisition.

The positive results of this study were not a coincidence. The e- book gives opportunities of discovery to find new ways in the interaction with information because it's a media format that contains audio, image, film, with interactive multimedia connections which can be read/watched in computers and similar devices [9]. Moreover the students as Pledger explained were able to listen to the text, change the font size and take notes and these extras led to a better understanding of the book contents [36]. In addition to the integration between the interactive e book and the different teaching strategies used by teacher in the classroom contributed to increase the success of the interactive e book in achieving the objectives of the study up to these results.

Many researches have revealed that interaction is a critical factor in developing an excellent e-learning environment. Ebooks facilitate written and visual communication between the participants who are at different places, enabling students to interact with other students and teachers; this kind of fast communication is an important factor in the improvement of 
the value of e-learning [13], [37] . Moreover, several researchers have pointed out that the use of e-books for social interaction constitutes an important role in the emergence of internet usage [16], [38].

\section{CONCLUSION}

The findings in this study indicated that there is effectiveness of the e book in developing the mathematical thinking skills, and mathematical concepts acquisition of the elementary $5^{\text {th }}$ grade students in Gaza, this contributes to the growing of the conviction of the importance of the e book.

The learning strategies used by teachers in the classroom increases the effectiveness of the computerized interactive book in education

\section{REFERENCES}

[1] Pearson, J., \& Trinidad, S. (2005). An instrument for refining the design of e-learning environments. Journal of Computer Assisted Learning, 21, 396-404.

[2] Thurmond, V. A., Wambach, K., Connors, H., \& Frey, B. (2002). Evaluation of student satisfaction: Determining the impact of a Web-based environment by controlling for student characteristics.The American Journal of Distance Education, 16(3), 169-189.

[3] Derting, T. L., \& Cox, J. R. (2008). Using a tablet pc to enhance student engagement and learning in an introductory organic chemistry course. Journal of Chemical Education, 85(12), 1638-1643.

[4] Siozos, P., Palaigeorgiou, G., Triantafyllakos, G., \& Despotakis, T. (2009). Computer based testing using "digital ink": Participatory design of a Tablet PC based assessment application for secondary education. Computers \& Education, 52(4), 811-819.

[5] Robb, M. B. (2010). New Ways of Reading: The impact of an interactive book on young children's story comprehension and parent-child dialogic reading behaviors. Ph.D. Dissertation, University of California, Riverside, USA. UC Riverside Electronic Theses and Dissertations. Retrieved on Jan. 5, 2015 from: http://escholarship.org/uc/item/5xm8n8xk

[6] Mitropoulou, V.( 2012) Interactive books for primary and secondary education for the course of religion in Greece, IADIS International Conference on Cognition and Exploratory Learning in Digital Age (CELDA 2012).269- 273. Retrieved on June 13, 2013 from: http://files.eric.ed.gov/fulltext/ED542826.pdf

[7] Wexelbaum, R. S.; Miltenoff, P.; and Parault, S. J. (2011). E-books and reading comprehension: perspectives of librarians and educators. Library Faculty Publications. Paper 2. Retrieved on Feb. 13, 2015from: http://repository.stcloudstate.edu/lrs_facpubs/2

[8] PC magazine(2015). PC magazine encyclopedia, EBook. Retrieved on Aug. 23, 2014 from: http://www.pcmag.com/encyclopedia/term/42214/e-book

[9] Hatipoglu N.\& Tosun N.(2012). The design of renewable and interactive e-book template for e-learning environments. Online Journal of Communication and Media Technologies. 2 (2), 126- 140.

[10] Chau, M.( 2008).The effects of electronic books designed for children in education .fis2309: design of electronic text, Vol. 1(1). Retrieved on Jan. 13, 2014 from http://fdt.library.utoronto.ca/index.php
[11] Borchers, J. (1999). Electronic books: definition, genres,interaction design patterns, Retrieved on September 22, 2014, from: https://hci.rwthaachen.de/materials/publications/borchers1999c.pdf

[12] Ongoz, S\& Baki, A. (2011). Examination of the impact of using an interactive electronic textbook on the affective learning of prospective mathematics teachers. Turkish Online Journal of Distance Education-TOJDE, 2(1).34- 45 .

[13] Chen, H. Y. \& , Jang, S.J.(2013). Exploring the reasons for using electric books and technologic pedagogical and content knowledge of taiwanese elementary mathematics and science teachers.

[14] Turkish Online Journal of Distance Education-TOJDE, 12(2).131- 141

[15] Beimers, K. D.(2014).Correlation between interactive ebooks and printed text in reading achievement and student interest. Master of Education Program Thesis, Paper 48. Department of Education- Dordt College. Retrieved on Jan. 13, 2015 from: htt://digitalcollections.dordt.edu/med_theses/48

[16] Maynard, S.(2005).Can electronic textbooks help children to learn?. The Electronic Library, 23(1), 103.

[17] Huang, Y. M. et al. (2012). Empowering personalized learning with an interactive e-book learning system for elementary school students. Educational Technology Research and Development, 60(4), 703-722.

[18] Grimshaw, S, et al. (2007). Electronic books: Children's reading and comprehension. British Journal of Educational Technology, 38(4), 583-599.

[19] Mullis, I. V.S., Martin, M. O. Foy,P., \& Arora, A.(2012). TIMSS 2011- International results in mathematics. International Association for the Evaluation of Educational Achievement (IEA).

[20] Mullis, I.V.S., Martin, M. O.m.,\& Foy,P.(2008). TIMSS 2007- International mathematics report: findings from IAE's trends in international mathematics and science study at the fourth and eighth grades. International Association for the Evaluation of Educational Achievement (IEA).

[21] Mullis , I. V.S. , Martin, M. O., Gonzalez, E. J.,\& Chrostowsk, S. J. ( 2004 ) . TIMSS 2003-International mathematics report. international association for the evaluation of educational achievement : findings from $I A E$ 's trends in international mathematics and science study at the fourth and eighth grades. International Association for the Evaluation of Educational Achievement (IEA).

[22] Abu Zaydah, A. A. \& Abu Zaydah H. Y. (2014). Effectiveness of a computerized interactive book in developing the visual thinking skills in technology for the fifth grade male students in gaza. International Journal of Computer Applications (0975 - 8887), 90 (9) ,7-11.

[23] Curri, E. (2012). Using computer technology in teaching and learning mathematics in an Albanian upper secondary school: the implementation of simReal in trigonometry lessons. Master's Thesis, Department of Mathematical Sciences, Faculty of Engineering and Science, University of Agder. 
[24] Yang, D. C., \& Tsai, Y. F. (2010). Promoting sixth graders' number sense and learning attitudes via technology-based environment. Educational Technology \& Society, 13(4), 112-125.

[25] Steen, K., Brooks, D., \& Lyon, T.(2006). The impact of virtual manipulatives on first grade geometry instruction and learning. The Journal of Computers in Mathematics and Science Teaching, 25(4), 373-391.

[26] Bolyard J.\& Moyer, P. (2006).The impact of virtual manipulatives on student achievement in integer addition and subtraction. PME-NA 2006 Proceedings: Technology , Vol.2, 879 - 881. Retrieved on June 13, 2013 from: http://www.pmena.org/2006/cd/index.htm

[27] de Jong, M. T., \& Bus, A. G. (2002). Quality of bookreading matters for emergent readers: an experiment with the same book in a regular or electronic format. Journal of Educational Psychology, 94(1), 145-155.

[28] Korat, O., \& Shamir, A. (2007). Electronic books versus adult readers: effects on children's emergent literacy as a function of social class. Journal of Computer Assisted Learning, 23(3), 248-259.

[29] Korat, O., \& Shamir, A. (2008). The educational electronic book as a tool for supporting children's emergent literacy in low versus middle SES groups. Computers \& Education, 50(1), 110-124.

[30] Liang, T.-H., \& Huang, Y.-M. (201 4). An investigation of reading rate patterns and retrieval outcomes of elementary school students with e-books. Educational Technology \& Society, 17 (1 ), 218-230.

[31] Azmi, N. \& Almerdani, M.(2010). The impact of the interaction between the different styles of learning scaffolding inside the e-book on achievement and learning efficacy among graduate education colleges students. Educational and Social Studies, Eygept.16(3),251-321.
[32] Al Amry, M.(2009). The impact of using e-book in teaching reading on achievement among 10th graders in saudi arebia. Research project, King Abdul-Aziz University, Jeddah, Saudi Arabia.

[33] Narayanan, N. H. \& Hegarty, M. (1998). On designing comprehensible interactive hypermedia manuals. International Journal of Human-Computer Studies, 48: 267-301, Academic Press.

[34] Khamis, M. A.(2003 a). Educational technology processing . Cairo: Der Al Hekmah.

[35] Khamis, M. A.(2003 b). Educational technology products . Cairo: Der Al Hekmah.

[36] Pallant, J. ( 2005) . SPSS Survival Manual: A step by step guide to data analysis using SPSS for Windows (Version 12), $2^{\text {nd }} e d$. National Library of Australia: Allen \& Unwin

[37] Pledger, P. (2010). Future of the Book? Challenge of the digital world. Presented at the 12th Biennial School Library Association of Queensland, the 39th International Association of School Librarianship Conference, incorporating the 14th International Forum on Research in School Librarianship. Brisbane, QLD Australia, 27 Sebtember-1October 2010.Retrieved on Feb. 15, 2015 from: http://www.slideshare.net/IASLonline/future-of-the-book

[38] Buckley, M., \& Tritt, D. (2011). E-book approval plans: integration to meet user needs. Computers in Libraries, 31(3), 15-18.

[39] Nunez-Valdez, E. R., et al.(2012). Implicit feedback techniques on recommender systems applied to electronic books. Computers in Human Behavior, 28(4), 1186-1193. 